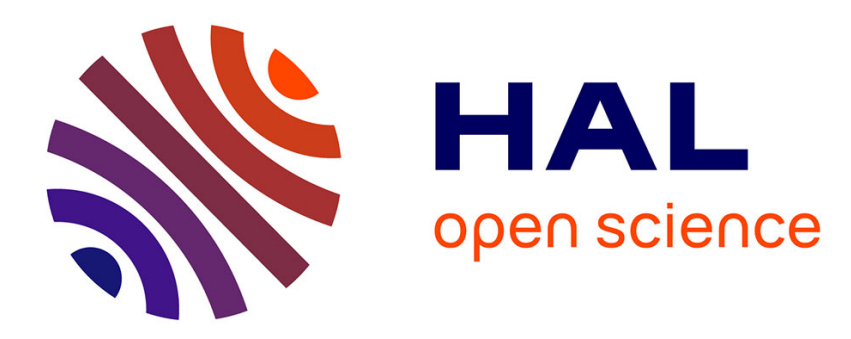

\title{
Financial systems, financing constraints, and investment: Empirical analysis of OECD countries
}

\author{
Radislav Semenov
}

\section{To cite this version:}

Radislav Semenov. Financial systems, financing constraints, and investment: Empirical analysis of OECD countries. Applied Economics, 2006, 38 (17), pp.1963-1974. 10.1080/00036840500427122 . hal-00581885

\section{HAL Id: hal-00581885 \\ https://hal.science/hal-00581885}

Submitted on 1 Apr 2011

HAL is a multi-disciplinary open access archive for the deposit and dissemination of scientific research documents, whether they are published or not. The documents may come from teaching and research institutions in France or abroad, or from public or private research centers.
L'archive ouverte pluridisciplinaire HAL, est destinée au dépôt et à la diffusion de documents scientifiques de niveau recherche, publiés ou non, émanant des établissements d'enseignement et de recherche français ou étrangers, des laboratoires publics ou privés. 


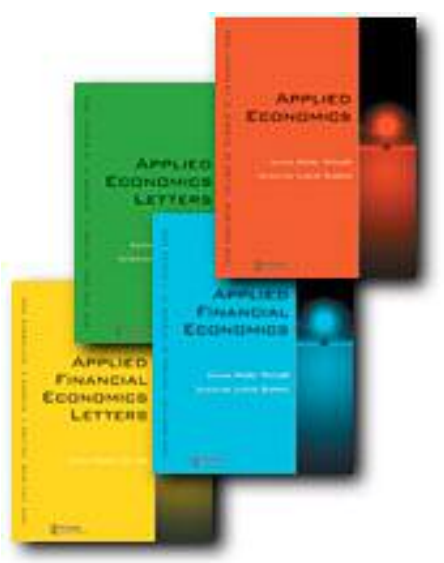

Financial systems, financing constraints, and investment: Empirical analysis of OECD countries

\begin{tabular}{|r|l|}
\hline Journal: & Applied Economics \\
\hline Manuscript ID: & APE-04-0141.R1 \\
\hline Journal Selection: & Applied Economics \\
\hline Date Submitted by the \\
Author: & 03-Jun-2005 \\
\hline JEL Code: & $\begin{array}{l}\text { G21 - Banks|Other Depository Institutions |Mortgages < G2 - } \\
\text { Financial Institutions and Services < G - Financial Economics, G32 - } \\
\text { Financing Policy|Capital and Ownership Structure < G3 - Corporate }\end{array}$ \\
\hline Keywords: & $\begin{array}{l}\text { financing constraints, financial systems, investment, bank-firm } \\
\text { relationships }\end{array}$ \\
\hline &
\end{tabular}

powered by ScholarOne

Manuscript Central ${ }^{\text {TH }}$ 


\title{
Financial systems, financing constraints, and investment: Empirical analysis of OECD countries
}

\author{
Financial systems, financing constraints, and investment
}

\begin{abstract}
This paper investigates the influence of cash flow on corporate investment in eleven OECD countries. We find that the sensitivity of investment levels to internally available funds differs significantly across countries, and is lower in countries with predominantly close bank-firm relationships than in countries with predominantly arm's-length bank-firm relationships. At the same time, we find no relationship of the levels of financial constraints to indicators of overall financial development. Our results are consistent with the view that information and incentive problems in the capital market have important effects on corporate investment, and that close bankfirm relationships can reduce these problems and thus improve the access of firms to external finance.
\end{abstract}




\section{Introduction}

Companies in various countries operate under dramatically different financial systems. The differences in the level of development of financial systems (as reflected, for example, in the volume of credit relative to gross domestic product (GDP) and the relative stock market capitalization relative to GDP), in patterns of relationships of owners and managers, of firms and creditors, the level of activity of the market for corporate control are well documented. Do these differences influence the investment patterns of firms in these countries?

In a perfect capital market, funds will always be available to firms with positive net present value investment opportunities. However, economic theories suggest that market frictions such as information asymmetries and incentive problems may make external capital more costly for firms, and firms with profitable investment opportunities may not always obtain necessary capital. This implies that financial factors, such as the volume of internally generated funds and the availability of new debt and equity, determine the firms' investment decisions. There is now a large empirical literature that investigates the influence of the availability of external funds on corporate investment decisions (see e.g. Fazzari et al. (1988), Hoshi et al. (1991), Chapman et al. (1996), Samuel (1998)). Most studies find that financial variables such as cash flow help to explain investment levels of firms. This finding is interpreted as suggesting that firms are constrained in their investment by availability of external funds.

Many models emphasize that well-functioning financial intermediaries and markets ameliorate information asymmetries and transaction costs, mitigate risks and thereby mobilize savings for investment in longer-term and higher-return projects and foster efficient resource allocation (see the review by Levine (1997)). We thus may 
expect that firms in countries with more developed financial systems will have a better access to external finance.

Several authors have suggested that establishing close relationship between firms and financial institutions mitigates financial market frictions still further. Thus, given the level of development of a financial system, firms with close ties to financial institutions should have a lower cost of capital and greater availability of funds relative to firms without such ties. A number of studies have found that firm-creditor relationships indeed improve the access of firms to external finance. We may therefore expect that firms in countries where close bank-firm relationships predominate to be less financially constrained than firms in countries where arm'slength bank-firm relationships predominate.

A number of studies undertaking cross-country comparisons of investmentcash flow sensitivity suggest that the effects of these characteristics of financial systems may indeed be important. Thus, the literature finds that investment is more sensitive to cash flow in the USA than in France (Mulkay et al., 2000), in the UK than in Germany (Bond et al., 1999), and in the UK than in Belgium, France and Germany (Bond et al., 2003). The authors of the last two papers argue that these differences are likely to be caused by differences in financial systems. Two or four countries, of course, may differ in many aspects of financial systems, and may also differ on other factors influencing investment decisions of firms. It is difficult to draw strong inferences about the effects of financial systems from the results of the papers mentioned. Such inferences would require a direct econometric analysis of a relationship between the indicators of financial systems and the indicators of financial constraints on investment, on a larger sample of countries. Two studies undertake such an investigation. Demirguc-Kunt and Maksimovic (1998), for large samples of 
firms in 26 countries, calculate the proportion of firms in a country that were growing faster than they could have using only internally generated funds. They show that this proportion is positively related to financial development. As Love (2001) notes, this analysis says little about the efficiency of fund allocation: it is unclear whether the firms that grew at a higher rate were the ones with the best investment opportunities. Love (2001), for a sample of firms from 40 countries, establishes that firms in countries with more developed financial systems are less financially constrained. Her analysis, however, has some technical problems which could have lead to biased results. Neither study investigates the influence of the character of investor-firm relationship on investment decisions.

This paper aims at investigating whether differences in financial systems (both in financial development and in the character of investor-firm relationship) affect the financial constraints the firms face. We construct a panel dataset for manufacturing firms in eleven developed countries ${ }^{1}$ and use it to estimate to what extent investment levels of firms in different countries are sensitive to the availability of internal funds. We then investigate whether differences in these sensitivities are related to the characteristics of financial systems of the countries.

The rest of the paper is organized as follows. The theoretical arguments suggesting the directions of influence of financial systems on the availability of external finance for firms are discussed in Section 2, and the relevant empirical literature is discussed in Section 3. Section 4 discusses methodology and data, and Section 5 presents the results of the analysis. Section 6 concludes.

\section{Theory}

From the perspective of the neoclassical theory, as the famous analysis by Modigliani and Miller (1958) has established, investment decisions of a firm are 
independent of the capital structure choice. Perfect capital markets ensure that external funds are perfect substitutes for internal capital. Firms are thus indifferent between various means to finance their investment. Numerous theoretical studies have argued, however, that the assumption of perfect capital markets cannot be maintained. Most important among capital market imperfections are the problems of asymmetric information. Myers and Majluf (1984) show that if managers are better informed than investors about the firm's prospects, the firm's risky securities will sometimes be underpriced, thereby raising the costs of external finance. Jensen and Meckling (1976) argue that interests of owners diverge in several important ways from interests of creditors: owners prefer riskier projects, have an incentive to issue a new debt senior to the existing one (thus increasing the risk for existing creditors), when a risk of bankruptcy is present, have an incentive to expropriate assets from the firm, and in bankrupt states have no incentive to apply efforts to improve the returns. These incentive problems raise the cost of credit.

The literature thus suggests that, because of information and incentive problems, external finance is more expensive than internal funds. Firms therefore may face financing constraints, which means that financial factors, such as the volume of internally generated funds and the availability of new debt and equity, will influence the firms' investment decisions.

More developed financial systems are likely to increase the availability and reduce the cost of capital for firms (see the review by Levine (1997)). Financial intermediaries and securities markets provide vehicles for trading, pooling, and diversifying risks, and thus mitigate the risks associated with individual firms, industries, regions, countries, etc., and induce a portfolio shift towards projects with higher expected return. Financial intermediaries allow individuals to economize on 
the costs of acquiring and processing information about investments. This facilitates the acquisition and processing of information, allows better selection of the most promising projects, and thereby improves resource allocation. Financial intermediaries also allow to pool, and thus economize on, monitoring costs. Stock markets facilitate the acquisition and dissemination of information about firms. By linking managerial compensation to stock prices owners can align the interests of managers with theirs. Developed stock markets facilitate the functioning of the market for corporate control, which further aligns the interests of managers with those of the owners. All this increases the incentives of individuals to invest in riskier projects with higher return and in long-term projects, and facilitates the mobilization of individual savings for investment in such projects. We therefore expect firms in countries with more developed financial systems to be less financially constrained than firms in countries with less developed financial systems.

Close bank-firm relationships are likely to increase the availability and reduce the cost of capital for firms. "Through close and continued interaction, a firm may provide a lender with a sufficient information about, and a voice in, the firm's affairs so as to lower the cost and increase the availability of credit" (Petersen and Rajan, 1994, p. 5). The amount of this information, and the strength of this 'voice', are even larger if lenders also own equity stakes in firms, as is the case in countries such as Germany and Japan.

Close relationship may facilitate provision of capital to firms in financial distress but with viable prospects. A bank may provide capital to such a firm, if it repays to the bank when the firm's financial conditions improve. But such a firm has an incentive to renege on such an agreement, and thus cannot credibly commit itself 
without additional arrangements. Long-term close bank-firm relationship helps to resolve this problem (Mayer, 1988).

Under close bank-firm relationships both parties have a better understanding of each other, monitoring costs are reduced (Lehmann and Neuberger, 2001). Contracts can be renegotiated at a lower cost (Sako, 1992; Elsas and Krahnen, 1998). If a bank is both a creditor and a shareholder of a firm, the firm has less incentive to take actions that benefit one class of investors at the expense of another (Aoki, 1984), and conflicts that arise among investors when a firm is near default are reduced (Hoshi et al., 1991). During periods of tight money, a bank is less likely to sharply increase interest rates to firms with which it has close relationships to firms the relationships with which are arm's-length (Congigliani e.a., 1997). Finally, a bank's involvement with a firm signals the firm's creditworthiness to other investors (Audretsch and Elston, 1999).

To summarize, the theory predicts that close banking ties are likely to increase availability and decrease the cost of capital to firms. We would therefore expect firms in countries where close bank-firm relationships predominate to be less financially constrained than firms in countries where arm's-length bank-firm relationships predominate.

\section{Related empirical literature}

Our paper is related to several strands of recent empirical literature. Two papers analyse whether firms with close bank relationships face weaker financial constraints on investment. Hoshi et al. (1991) find this to be the case for Japanese firms, and Audretsch and Elston (1999) - for German firms. Becht and Ramirez (2003) show that in the pre-World War I period German the firms in mining and steel industries that were not affiliated with one of the large universal banks were 
financially constrained, while this was not the case for firms affiliated with banks. Houston and James (2001) find that, among 250 large US firms, those with a relationship with a single bank are less financially constrained, provided that the investment is not too large (less than 100 percent of capital stock), but firms requiring larger investments are more constrained when they have a single bank. It is important to note, though, that a relationship with a single bank would not necessarily be 'close'.

Several other papers establish that close bank-firm relationships increase availability and reduce the costs of debt finance to firms. Petersen and Rajan (1994) argue that trade credit is the most expensive external source of finance, and so firms that use trade credit more are likely to be debt-constrained. For a sample of about 3400 US enterprises with fewer than 500 employees, they find that the extent of trade credit usage is negatively related to the duration of existing lending relationships. Petersen and Rajan find that interest rates charged by banks are not related to the duration of lending relationships. This result is confirmed by Blackwell and Winters (1997) who use records of bank loans to small and medium enterprises; the authors show, however, that interest rates are lower when loan commitments from the bank represent a larger fraction of the firm's total debt. Berger and Udell (1995), using the same dataset as Petersen and Rajan (1994), find that firms with longer lending relationships have to pledge collateral less frequently and have to pay lower interest rates on loan commitments. Weinstein and Yafeh (1994) find that small Japanese firms with close bank relationships are more capital-intensive, indicating weaker financial constraints on investment. For German SMEs, Harhoff and Körting (1998) and Lehmann and Neuberger (2001) find that 'house banks' provide credit more readily and at lower interest rates, and Elsas and Krahnen (1998) find that 'house 
banks' provide liquidity insurance in situations of unexpected deterioration of borrower rating (although they do not find evidence that 'house banks' charge lower interest rates). For Japan, Hoshi et al. (1990) find that firms with strong ties to the 'main bank' are more able to invest when they are financially distressed. For Italy, recent work shows that credit access increases with the exclusiveness and duration of the relationship between a firm and a bank (see the review in Foglia et al., 1998). D'Auria et al. (1999) find that the closeness of lending relationship, measured by a bank's share of the customer's debt, is the main determinants of individual loan rates for large and medium firms, with large shares associated with lower interest rates.

The literature also suggests that firms in countries with more developed financial systems (as measured by the volume of credit and the relative stock market capitalization, relative to GDP) are less financially constrained. Rajan and Zingales (1998), for a sample of 49 countries, find that manufacturing industries with higher external capital requirements grow faster in countries with higher financial development. Demirguc-Kunt and Maksimovic (1998), for a sample of firms in 26 countries, calculate the proportion of firms in a country that were growing faster than they could have using only internally generated funds. They show that this proportion is positively related to financial development. Love (2001), for a sample of firms from 40 countries, establishes that firms in countries with more developed financial systems are less financially constrained. Love conducts two kinds of tests. First, she estimates a model on the sample pooling all countries, including the interaction term of cash variable with country-level indicators of financial development. This test is problematic, however, because the assumption that the influence of other factors influencing investment decisions is similar across countries is questionable. Second, she estimates regressions for individual countries, and regresses the cash coefficients 
obtained in them on country-level indicators of financial development. This second test is also the one we conduct in this paper. We have, however, refrained from using the coefficients obtained by Love, and decided to construct our own dataset and conduct our own estimations. There are two reasons for this. First, contrary to all other authors, Love uses a sample of all non-financial firms and not just manufacturing firms. The investment behaviour of non-manufacturing firms may differ significantly from that described in traditional investment models (see e.g. Whited, 1992), as Love herself admits ${ }^{2}$. Second, there are econometric problems involved in Love's analysis. The author uses the Generalized Method of Moments (GMM) for estimation on the panel data with often very few firms (less than 100 firms for 20 out of 40 countries). Mulkay et al. (2000), for samples of firms from France and the US, find that instruments usually used in estimations of investment equations (and used by Love) are very weak in their case. Recently the evidence has accumulated that the use of GMM where only weak instruments are available produces very imprecise estimates of coefficients, which are also possibly biased when the sample size is not very large (less than about 500 units) (see Mulkay et al. (2000) and references therein). As Mulkay et al. note, "this feature of GMM is especially problematic for comparative purposes because it implies that we will accept similarity of behavior between countries... when it is not present" (p. 3). It is suggestive that only 9 out of 40 cash coefficients in Love's estimations for individual countries are significantly different from zero at conventional levels. For countries in our sample, only one is significantly different from zero. It is likely that the weakness of instruments and the resulting imprecision of estimates are responsible for this result. In any case, it would be inappropriate for us to make inferences about cross- 
country differences on the basis of coefficient all but one of which do not differ significantly from zero (and, in most cases, from each other) and are possibly biased.

There are other papers comparing the investment-cash flow sensitivity of firms across countries. Bond et al. (1999) find that this sensitivity is higher for British than for German firms, Bond et al. (2003) - that it is higher for British than for Belgian, French and German firms, and Mulkay et al. (2000) - that it is higher for the US than for French firms.

\section{Methodology and data}

We use the following methodology to analyse the effect of financial systems on the sensitivity of corporate investment to the availability of internal funds. First, we estimate the sensitivity of investment level to cash flow for firms in each country. We then regress the coefficients estimated in these regressions on variables reflecting the character of financial systems in these countries ${ }^{3}$.

The econometric model we estimate in the first step is based on the $q$-theory framework. Absent capital market imperfections, the value-maximizing firm will invest as long as the shadow value of an additional unit of capital, marginal Tobin's $q$, exceeds unity. $q$ thus represents the market's evaluation of the firm's investment opportunities. In the absence of capital market imperfections, cash flow should be irrelevant. A finding that cash flow does matter for investment levels, given $q$, is taken as evidence of a financial constraint. Since marginal $q$ is not observable, researchers have used average $q$ in their estimations.

In the first step we run the following regression:

$$
\frac{I_{t}}{K_{t}}=\alpha+\beta_{1} Q_{t}+\beta_{2}\left(\frac{S_{t-1}}{K_{t-1}}\right)+\beta_{3}\left(\frac{C F_{t-1}}{K_{t-1}}\right)+\gamma_{t}+\varepsilon_{i t}
$$


Here $I_{t}$ is the firm's capital expenditures during the year. $K_{t}$ is the stock of capital at the current replacement cost at the beginning of the year. To calculate it, we use a standard perpetual inventory method: $K_{t}=(1-\delta) K_{t-1}+I_{t}$, where $\delta$ is depreciation rate. The starting value was based on the net book value of plant, property and equipment in the first year for which the data for the firm are available. The rate of depreciation was assumed to equal $8 \%$, and the price indices were obtained using the GDP deflator from IMF (2001). $Q_{t}$ is market-to-book value at the beginning of the year, which controls for the attractiveness of investment opportunities. $S_{t}$ are sales during the years, included to control for the accelerator effect. Finally, our measure of liquidity is $C F_{t}$, cash flow generated during the period, obtained as net income before dividends plus depreciation, depletion and amortization allowances.

We control for the effects of business cycles by including year dummies. We control for firm-specific effects by employing the within estimator: all variables employed in the regressions are differences from the mean value for a given firm.

All firm-level data come from the Worldscope database. This database contains the information on the majority of the publicly traded companies in each country. An attempt is made by Worldscope to standardize accounting information to improve cross-country comparability. The data cover the years 1993-2000.

Our initial sample included all firms with a primary activity in manufacturing (primary SIC codes from 2000 to 3999) with four or more years of continuous data on all raw indicators. We excluded subsidiaries of foreign firms. It may be argued that very large firms have access to international capital markets, and the features of the national financial system are unlikely to influence much their access to external finance. It may also be argued that in all financial systems banks monitor small firms closer than medium and large firms, and the relationships of a significant proportion 
of small firms with banks are close in all systems (see Berger and Udell (1995) for the USA and Binks and Ennew (1998) for the UK). The difference between the countries where bank-firm relationships are predominantly close and the countries where they are predominantly arm's-length is that in the former countries the relationships of firms with banks become arm's-length at a much later point in the firm's development (and at a much larger size) than in the latter countries (see e.g. Vitols, 1997). To infer whether differences in financial systems have implications for investment decisions, we therefore should exclude small and very large firms from the sample. This also makes samples more comparable across countries, since in some countries much more small firms are included in Worldscope's database than in others. Accordingly, we excluded all firms with the volume of sales in their last year in the sample smaller than $\$ 50 \mathrm{mln}$, and all firms with the volume of sales in their last year in the sample larger than $\$ 10$ bln. In order to obtain the measures of variables which are consistent over time we made an effort to take into account major merger and acquisition activities. In particular, if the value of net plant, property and equipment in a particular year differed by a factor of 3 or more from that of the previous year, we excluded this observation and all observations for years either before or after it (retaining the longer sequence of observations). The sample was cleaned to reduce the influence of outliers. Basically we excluded all observations with zero values of $K, I$ or $S$, observations with negative market-to-book ratio, and trimmed the data so that one percent of observations in the upper tail of each variables, and in the lower tail of cash flow ratio, were removed. After this procedure, some firms had less than four years of continuous data; these firms were excluded from the sample.

Our final sample includes 2601 firms with 11979 observations. Table 1 shows the numbers of firms and observations per country, and the means and standard 
deviations of the variables by country. It can be seen that American and French firm have the highest mean values of investment, cash flow and sales ratios, and the highest standard deviations of these ratios. Japanese firms have the lowest mean values of investment and cash flow ratios, and the second lowest sales ratio, while Italy has the second lowest mean values of investment and cash flow ratios, and the third second lowest sales ratio. Japanese firms have the lowest standard deviation of investment and cash flow ratios, with Australian and Dutch firms also having low standard deviations.

We turn now to country-level variables reflecting the characteristics of the financial system. We characterize financial development by the volume of credit by deposit money banks and other financial institutions to the private sector relative to GDP, and the value of stock market capitalization relative to GDP. These indicators have been widely used to proxy for financial development (see e.g. Demirguc-Kunt and Maksimovic, 1998; Love, 2001). The values of these variables are reported in columns 1 and 2 of Table 2.

We characterise the closeness of bank-firm relationships in a country by two variables. The first is the proportion of total stock market capitalization held by banks. The values are reported in column 3 of Table 2. Our second indicator of the closeness of bank-firm relationship is build on the basis of the informed opinions of researchers on the character of firm-bank relationships in various countries. In the countries in our sample, bank-firm relationships are characterized as predominantly close in Finland, Germany and Japan, and as predominantly arm's-length in Australia, Canada, France, Italy, the Netherlands, Spain, the UK, and the USA ${ }^{4}$. Our second variable reflecting closeness of bank-firm relationships is thus a dummy equal to 1 for countries with predominantly close bank-firm relationships - Finland, Germany and Japan, - and to 
0 for other countries. Note that the countries where close bank-firm relationships play an important role according to the informed experts' opinion - Finland, Germany and Japan - have higher values of the bank equityholdings than the rest of the countries.

\section{Results}

Table 3 presents the results of the estimations of investment equations for the eleven countries. We observe that the coefficients of market-to-book ratio and lagged sales generally have the expected positive signs and are significant. We also observe that coefficients of cash flow ratio in countries with predominantly close bank-firm relationships are lower than in countries with predominantly arm's-length bank-firm relationships. Moreover, coefficients in all countries of the former group are not significantly different from zero at conventional levels, while coefficients in all countries of the latter group are significantly different from zero. This suggests that firms in countries with predominantly close bank-firm relationships are less financially constrained than firms in countries with predominantly arm's-length bankfirm relationships.

This is confirmed by the more formal analysis. We regress the coefficients of cash flow ratios obtained in these regressions on the variables characterizing the financial systems of individual countries. The results are reported in Table 4. The regression on bank equityholdings explains a large part of variance, and the coefficient of the variable is significant with the expected negative sign. In the regression on the dummy for countries with predominantly close bank-firm relationships, the coefficient of the dummy is highly significant, and the regression explains more than 60 percent of variation in the dependent variable. At the same time, for regressions the cash flow coefficients on the variables reflecting financial development - the volume of credit relative to GDP and the volume of stock market 
capitalization relative to GDP - the joint significance of the coefficients is far below conventional levels, and in the former case the adjusted $R^{2}$ is negative. The coefficients of the financial variables are not significant. This indicates that in developed countries the differences in investment-cash flow sensitivity are not related to the differences in financial development. In estimations with more than one regressor included the values and significance of coefficients are very close to those in bivariate regressions.

\section{Discussion}

The results presented in this paper are consistent with the findings of earlier studies that document the value of a close banking relationship. Our results are also consistent with the results of the previous cross-country comparisons of financial constraints on the firms' investment (Bond et al., 1999; Mulkay et al., 2000; Bond et al., 2003). As in these studies, we find that the firms in the USA and the UK are more financially constrained than the firms in France and Germany. Bond e.a. (1999) and Bond et al. (2003) argue that their findings suggest that firms in more 'marketoriented' Anglo-Saxon systems are more financially constrained than the firms in (less 'market-oriented') continental European systems. Our results suggest that this inference is not quite correct. There are several continental European countries in our sample, with financial systems that could not be easily classified as 'market-oriented', in which firms are more financially constrained than in the UK and the USA. The results of our analysis suggest that it is not 'market orientation' per se that is related to stronger financial constraints but the arm's-length character of bank-firm relationships.

Our results for the relationship of financial constraints to financial development differ from those obtained by Demirguc-Kunt and Maksimovic (1998) 
and by Love (2001), who find a significant negative relationship. These results and ours do not necessarily contradict each other, however. The authors of these two papers employ larger samples of countries which include both developed and developing countries. While there are significant differences among developed countries in the level of financial development, the level of financial development in developed countries is generally higher than that in developing countries (especially as far as the development of credit market is concerned). It is likely that financial development matters for the access of firms to external finance, but once financial development reaches a certain level its further increase per se does not improve this access; other factors (such as the character of relationships of firms and investors) play a more important role. It is also possible that the character of industrial development in developed countries differs significantly from that in developing countries, ensuring that the factors most significantly influencing the availability of external finance for investment differ between the two groups of countries.

In all countries, of course, there are both firms with arm's-length relationships and firms with close relationships with creditors. However, in most countries a vast majority of firms are of one of these types. There are significant forces ensuring that this would be the case. Deviating from a predominant pattern has costs of various kinds. The regulatory environment almost always supports a predominant type of relations in a country and makes it more costly (sometimes prohibitively costly) to enter into a different type of relations (see e.g. the discussion of the US regulatory environment by Roe (1994)). Various institutions would have developed in a country to facilitate the working of the predominant system (Bebchuk and Roe, 1999). Close relationships are based on mutual trust of the parties, and in an environment where the culture of such trust is not present close relationship may be difficult to establish (e.g. 
Sako, 1992). The firms and financiers may continue to use the arrangement which they used in the past because they are familiar with these arrangements (but would have to adjust to new ones), or because the old arrangements have led to acceptable results, while the effectiveness of other arrangements is uncertain (Fligstein, 1990; Bebchuk and Roe, 1999). New firms may use the same arrangements as successful established firms in the field (Fligstein, 1990). Some arrangements may become to be considered as standard or natural and be used by agents without much contemplation (Fligstein, 1990). Particular practices may be institutionalized within the business community, and a willingness of an agent to enter them may be considered as a signal of her trustworthiness (Powell, 1991). Several authors (e.g. Soskice, 1996, 1999; Streeck, 1997; Whitley, 1999; Hall and Soskice, 2001) have argued that the character of the financial system is closely interlinked with the character of other aspects of the economic system, and together they form distinctive national patterns of economic organization (for example, the character of relationship among managers and employees in Germany would be very difficult to sustain without close relationships between firms and banks). Moreover, it has been argued that these distinctive patterns are deeply embedded in the social system in general (e.g. Hollingsworth, 1997; Orru, 1997).

Some may argue that the distinction between financial systems with predominantly arm's-length bank-firm relationships and predominantly close bankfirm relationships is becoming meaningless in a world of increasingly global financial markets. However, the evidence suggests that financial markets are far from integrated, and many arguments exist suggesting that such integration is unlikely to eliminate differences in national financial systems (see e.g. Berger (1996)). In particular, there is little evidence of a decline in the importance of main bank system 
in Japan. While in 1980s there were signs that some largest Japanese firms weakened their connections with main banks, the importance of the main bank system did not diminish. In the 1970-90s Japanese companies increased the share of borrowing from the main bank; the proportion of firms which changed the main bank decreased for medium-size firms; the number of directors dispatched from city banks to other listed companies increased by 34 percent from 1980 to 1993 (Corbett, 1998). Differences found in this paper between in many respects similar companies in different countries indicate that national financial systems continue to matter when it comes to raising finance for investment.

Fixed investments are not the only type of firms' expenditures sensitive to capital market imperfections. Several studies find that this is also the case for inventory investments (e.g. Kashyap et al., 1994; Guariglia, 1999; Bo et al., 2002) and R\&D expenditures (e.g. Rafferty and Funk, 2004). It is therefore likely that close relationships with banks also reduce the liquidity constraints on these types of expenditures.

Our finding that stock market development does not help to overcome capital market imperfections is consistent the results of the previous literature indicating a limited importance of stock market for the firms' investments. Mayer (1988) and Röell (1996) established that firms in general do not use proceedings from equity issues for new investment. Morck et al. (1990) and Samuel (2001) find that that stock market signals are of very limited importance for the firms' investment decisions compared to the managers' own perception of fundamentals facing the firm.

One should be cautious in deriving strong conclusions from our results. We have not explored the question of whether the 'softer' budget constraints in the countries with closer bank-firm relationships just allow an increase in investment 
towards the optimal level, or also investment beyond the optimal level. Theoretical literature argues that close bank-firm relationships make it more difficult for lenders to precommit not to refinance long-term low-return projects at the interim date (Dewatripont and Maskin, 1995). In addition, the banks that are also important shareholders may insure that the firm chooses projects with higher needs for finance over those needing less finance (Baums, 1994). Thus, overinvestment may occur in systems with predominantly close bank-firm relationships.

Despite this caveat, the evidence presented in this paper is highly suggestive. Close bank-firm relationships appear to significantly reduce capital market imperfections and lead to higher availability of investment financing for firms. It indicates that, to the extent close bank-firm relationships are more difficult to form in some countries than in others, this may offer firms in such countries an important source of comparative advantage. In particular, we may expect that these countries may have a comparative advantage in more capital-intensive industries. Our results also suggest that firms from countries where bank-firm relationships are closer may on average be more capital-intensive, and increase in capital intensity would for them represent a more important source of productivity growth than for firms in countries with predominantly arm's-length bank-firm relationships. Investigation of these issues can be a fruitful avenue of future empirical research. An indication that these factors may be important is provided by the study of foreign-owned firms in the UK manufacturing by Wang et al. (2002). The authors find that Japanese- and Europeanowned (but not US-owned) firms are significantly capital-intensive more than indigenous UK firms, and this is one of the factors behind the higher productivity of these firms compared to the indigenous firms. On the basis of our findings one can conjecture that higher capital intensity of Japanese- and European-owned subsidies is 
related to lower liquidity constraints on investment for firms from Japan and some European countries, due to the character of their relationships with banks.

\section{Conclusion}

This paper investigates the influence of cash flow on corporate investment in eleven developed countries. We find that the sensitivity of investment levels to internally available funds differs significantly across countries. Coefficients of cash flow ratio in countries with predominantly close bank-firm relationships are lower and not significantly different from zero at conventional levels, and coefficients in countries with predominantly arm's-length bank-firm relationships are higher and are significantly different from zero. At the same time, we find no relationship of the levels of financial constraints to indicators of financial development - the volume of credit and the relative stock market capitalization, relative to GDP. Our results are consistent with the view that information and incentive problems in the capital market have important effects on corporate investment, and that close bank-firm relationships can reduce these problems and thus improve the access of firms to external finance. 
${ }^{1}$ The countries are Australia, Canada, Finland, France, Germany, Italy, Japan, the Netherlands, Spain, the United Kingdom, and the United States. The set of countries for which the analysis could be undertaken was determined by the availability of data for the character of bank-firm relationship and by the necessity of having a sufficient number of firms for estimations.

${ }^{2}$ Love notes that she has conducted the first type of tests using manufacturing firms only, and that the results are similar to those for the whole sample. Love, however, does not conduct the second type of tests for manufacturing firms; the coefficients of regressions for individual countries are thus not available.

${ }^{3}$ This methodology is also used by Love (2001). A similar methodology is used by Demirguc-Kunt and Maksimovic (1998).

${ }^{4}$ The references include: for Finland, Seppänen (2000); for Germany, Baums (1994); for Japan, Aoki (1994); for Australia, Kenworthy (1995); for Canada, Morck and Nakamura (1995); for France, Quack and Hildebrandt (1995) and Hancké and Soskice (1996); for Italy, Barca e.a. (1998); for the Netherlands, Bolt and Peeters (1997); for Spain, Garcia and Ocaña (1997); for the UK and the USA, Chew (1997). 


\section{References}

Aoki, M. (1994) Monitoring characteristics of the main bank system: an analytical and developmental view, in The Japanese Main Bank System: Its Relevance for Developing and Transforming Economies (Eds.) M. Aoki, H. Patrick, Oxford University Press, Oxford, pp. 81-108.

Audretsch, D.B. and Elston, J.A. (1999) Does firm size matter? Evidence on the impact of liquidity constraints on firm investment behaviour in Germany, International Journal of Industrial Organization, 20, 1-17.

Barca, F., Ferri, G. and Pesarezi, N. (1998) Banks and corporate governance in Italy: a two-tier system, in Corporate Governance, Financial Markets and Global Convergence (Eds.) M. Balling, E. Hennessy and R. O'Brien, Kluwer Academic Publishers, Dordrecht, pp. 16-39.

Baums, T. (1994) The German banking system and its impact on corporate finance and governance, in The Japanese Main Bank System: Its Relevance for Developing and Transforming Economies (Eds.) M. Aoki and H. Patrick, Oxford University Press, Oxford, pp. 409-49.

Bebchuk, L. and Roe, M. (1999) A theory of path dependence in corporate governance and ownership, Columbia Law School, The Center for Law and Economics Studies, working paper.

Becht, M. and Ramrrez, C. D. (2003) Does bank affiliation mitigate liquidity constraints? Evidence from Germany's universal banks in the pre-World War I period, Southern Economic Journal, 70, 254-72.

Berger, S. (1996) National diversity and global capitalism: Introduction, in National Diversity and Global Capitalism (Eds.) S. Berger and R. Dore, R., Cornell University Press, Ithaca, pp. 1-25. 
Berger, A.N. and Udell, G.F. (1995) Relationship lending and lines of credit in small business finance, Journal of Business, 68, 351-81.

Binks, M.R. and Ennew, C.T. (1998) The relationship between U.K. banks and their small business customers, Small Business Economics, 9, 167-78.

Blackwell, D.W. and Winters, D.B. (1997) Banking relationships and the effect of monitoring on loan pricing, Journal of Financial Research, 20, 275-89.

Bo, H., Kuper, G., Lensink, R. and Sterken, E. (2002) Dutch inventory investment: are capital market imperfections relevant?, Applied Economics, 34, 15-22. Bolt, W. and Peeters, M. (1997) Corporate governance in the Netherlands, De Nederlandsche Bank, Reprint Series.

Bond, S., Elston, J., Mairesse, J. and Mulkay, B. (2003) Financial Factors and investment in Belgium, France, Germany and the UK: a comparison using company panel data, Review of Economics and Statistics, 85, 153-165.

Bond, S., Harhoff, D. and van Reenen, J. (1999) Investment, R\&D and financial constraints in Britain and Germany, Institute for Fiscal Studies, working paper.

Carlin, W. and Mayer, C. (2003) Finance, investment, and growth, Journal of Financial Economics, 69, 191-226.

Carpenter, R.E., Fazzari, S.M. and Petersen, B.C. (1994) Inventory investment, internal-finance fluctuations, and the business cycle, Brookings Papers on Economic Activity, 2, 75-138.

Chapman, D.R., Junor, C.W. and Stegman, T.R. (1996) Cash flow constraints and firms' investment behaviour, Applied Economics, 28, 1037-44. 
Chew, D.H., ed. (1997) Studies in International Corporate Finance and Governance Systems: A Comparison of the USA, Japan, and Europe, Oxford University Press, Oxford.

Congigliani, C., Ferri., G. and Generale, A. (1997) The impact of bank-firm relationships on the propagation of monetary policy squeezes: an empirical assessment for Italy, Banca Nazionale de Lavoro Quarterly Review, 202, 271-99.

Corbett, J. (1998) Changing corporate governance in Japan, in Corporate Governance, Financial Markets and Global Convergence (Eds.) M. Balling, E. Hennessy and R. O'Brien, Kluwer, Dordrecht, pp. 113-36.

D’Auria, C., Foglia, A. and Marullo Redttz, P. (1999) Bank interest rates and credit relationships in Italy, Journal of Banking and Finance, 23, 1067-93.

Demirguc-Kunt, A. and Maksimovic, V. (1998) Law, finance and firm growth, Journal of Finance, 53, 2107-31.

Dewatripont, M. and Maskin, E. (1995) Credit and efficiency in centralized and decentralized economies, Review of Economic Studies, 62, 541-56.

Elsas, R. and Krahnen, J.P. (1998) Is relationship lending special? Evidence from credit file data in Germany, Journal of Banking and Finance, 22, 1283-316.

Fazzari, S.M., Hubbard and R.G., Peterson, B. (1988) Financial constraints and corporate investment, Brookings Papers on Economic Activity, 1, 141-195.

Fligstein, N. (1990) The Transformation of Corporate Control, Harvard University Press, Cambridge (Mass.).

Foglia, A., Laviola, S. and Marullo Reddtz, P. (1998) Multiple bank relationships and the fragility of corporate borrowers, Journal of Banking and Finance, 22, 1441-56. 
Garcia, T. and Ocaña, C. (1997) The role of banks in relaxing financial constraints: some evidence on the investment behavior of Spanish firms, Universidad Carlos III de Madrid, Working Paper.

Guariglia, A. (1999) The effects of financial constraints on inventory investment: evidence from a panel of UK firms, Economica, 66, 43-62.

Hall, P.A. and Soskice, D., eds. (2001) Varieties of Capitalism: The Institutional Foundations of Comparative Advantage, Oxford University Press, Oxford.

Hancké, B. and Soskice, D. (1996) Coordination and restructuring in large French firms: the evolution of French industry in the 1980s, Social Science Research Center, Berlin, Discussion Paper.

Harhoff, D. and Körting, T. (1998) Lending relationships in Germany Empirical evidence from survey data, Journal of Banking and Finance, 22, 1317-53.

Hollingsworth, J.R. (1997) Continuities and changes in social systems of production: the cases of Japan, Germany, and the United States, in Contemporary Capitalism: The Embeddedness of Institutions (Eds.) J.R. Hollingsworth and R. Boyer, CambridgeUniversity Press, Cambridge, pp. 265-310.

Hoshi, T., Kashyap, A. and Scharfstein, D (1990) The role of banks in reducing the costs of financial distress in Japan, Journal of Financial Economics, 27, $67-88$.

Hoshi, T., Kashyap, A. and Scharfstein, D (1991) Corporate structure, liquidity, and investment: evidence from Japanese industrial groups, Quarterly Journal of Economics, 106, 33-60.

Houston, J.F. and James, C.M. (2001) Do relationships have limits? Banking relationships, financial constraints, and investment, Journal of Business, 74, 347-74. 
IMF (2001) International Financial Statistics, International Monetary Fund, Washington.

Jensen, M.C. and Meckling, W.H. (1976) Theory of the firm, managerial behavior, agency costs and ownership structure, Journal of Financial Economics, 3, $305-60$.

Kenworthy, L. (1995) In Search of National Economic Success: Balancing Competition and Cooperation, Thousand Oaks, Sage.

Lehmann, E. and Neuberger, D. (2001) Do lending relationships matter? Evidence from bank survey data in Germany, Journal of Economic Behavior and Organization, 45, 339-59.

Levine, R. (1997) Financial development and economic growth: views and agenda, Journal of Economic Literature, 35, 688-726.

Love, I. (2003) Financial development and financing constraints: International evidence from the structural investment model, Review of Financial Studies, 16, 765791.

Mayer, C. (1988) New issues in corporate finance, European Economic Review, 32, 1167-89.

Modigliani, F. and Miller, M.H. (1958) The cost of capital, corporation finance and the theory of investment, American Economic Review, 48, 261-97.

Morck, R. and Nakamura, M. (1995) Banks and corporate governance in Canada, in Corporate Decision-Making in Canada (Eds.) R. Daniels, R. Morck, University of Calgary Press, Calgary, pp. 481-502.

Mulkay, B., Hall, B.H. and Mairesse, J. (2000) Firm level investment and R\&D in France and the United States: A comparison, National Bureau of Economic Research, working paper. 
Myers, S. and Majluf, N. (1984) Corporate finance and investment decisions when firms have information that investors do not have, Journal of Financial Economics, 13, 187-221.

Orru, M. (1997) The institutional analysis of capitalist economies, in The Economic Organization of East Asian Capitalism (Eds.) M. Orru, N.W. Biggart, G.G. Hamilton, Sage, Thousand Oaks, pp. 297-310.

Petersen, M.A. and Rajan, R. (1994) The benefits of lending relationships: evidence from small business data, Journal of Finance, 49, 3-37.

Powell, W.W. (1991) Expanding the scope of institutional analysis, in The New Institutionalism in Organizational Analysis (Eds.) W.W. Powell, P.J. DiMaggio, University of Chicago Press, Chicago, pp. 183-203.

Quack, S. and Hildebrandt, S. (1995) Hausbank or fournisseur? Bank services for small and medium sized enterprises in Germany and France, Social Science Research Center, Berlin, Discussion Paper.

Rafferty, M. and Funk, M. (2004) Demand shocks and firm-financed R\&D expenditures, Applied Economics, 36, 1529-36.

Rajan, R.G. and Zingales, L. (1998) Financial dependence and growth, American Economic Review, 88, 559-86.

Roe, M.J. (1994) Strong Managers, Weak Owners: The Political Roots of American Corporate Finance, Princeton University Press, Princeton.

Röell, A. (1996) The decision to go public: an overview, European Economic Review, 40, 1071-1081.

Sako, M. (1992) Prices, Quality and Trust: Inter-Firm Relations in Britain and Japan, Cambridge University Press, Cambridge. 
Samuel, C. (1998) The investment decision: a re-examination of competing theories using panel data, Applied Economics, 30, 905-104.

Samuel, C. (2001) Stock market and investment: the signalling role of the market, Applied Economics, 33, 1243-52.

Seppänen, H.J. (2000) Discretionary disclosure and external financing in a relationship financing environment, Helsinki School of Economics and Business Administration, working paper.

Soskice, D. (1996) German technology policy, innovation, and national institutional framework, Social Science Research Center, Berlin, discussion paper.

Soskice, D. (1999) Divergent market regimes: coordinated and uncoordinated market economies in the 1980s and 1990s, in Continuity and Change in Contemporary Capitalism (Eds.) H. Kitschelt et al., Cambridge University Press, Cambridge, pp. 101-34.

Streeck, W. (1997) Beneficial constraints: On the economic limits of rational voluntarism, in Contemporary Capitalism: The Embeddedness of Institutions (Eds.) J.R. Hollingsworth and R. Boyer, CambridgeUniversity Press, Cambridge, pp. 197219.

Vitols, S. (1997) Are German banks different?, Small Business Economics, 10, $79-91$.

Wang, C., Sileri, P. and Liu, X. (2002) The relative economic performance of foreign subsidies in UK manufacturing, Applied Economics, 34, 1885-92.

Weinstein, D.E. and Yafeh, Y. (1998) On the costs of a bank-centered financial system: evidence from the changing main bank Relations in Japan, Journal of Finance, 53, 635-72. 
Whited, T.M. (1992) Debt, liquidity constraints, and corporate investment: evidence from panel data, Journal of Finance, 47, 1425-60.

Whitley, R. (1999) Divergent Capitalisms: The Social Structuring and Change of Business Systems, Oxford University Press, Oxford. 
Table 1

Summary statistics

\begin{tabular}{|c|c|c|c|c|c|c|}
\hline & \multicolumn{4}{|c|}{ Mean values (standard deviations) } & \multirow{2}{*}{$\begin{array}{l}\mathrm{N} \text { of } \\
\text { firms }\end{array}$} & \multirow{2}{*}{$\begin{array}{c}\mathrm{N} \text { of } \\
\text { observations }\end{array}$} \\
\hline & $\begin{array}{l}\text { Investment } \\
\text { /capital }\end{array}$ & $\begin{array}{c}\text { Cash flow } \\
\text { /capital }\end{array}$ & $\begin{array}{l}\text { Sales } \\
\text { /capital }\end{array}$ & $\begin{array}{l}\text { Market-to- } \\
\text { book }\end{array}$ & & \\
\hline Australia & $\begin{array}{c}0.188 \\
(0.093)\end{array}$ & $\begin{array}{c}0.283 \\
(0.176)\end{array}$ & $\begin{array}{c}3.477 \\
(1.767)\end{array}$ & $\begin{array}{c}2.055 \\
(0.669)\end{array}$ & 36 & 199 \\
\hline Canada & $\begin{array}{c}0.202 \\
(0.154)\end{array}$ & $\begin{array}{c}0.285 \\
(0.273)\end{array}$ & $\begin{array}{c}3.491 \\
(2.964)\end{array}$ & $\begin{array}{c}2.061 \\
(1.751)\end{array}$ & 97 & 514 \\
\hline Finland & $\begin{array}{c}0.181 \\
(0.146)\end{array}$ & $\begin{array}{c}0.298 \\
(0.257)\end{array}$ & $\begin{array}{c}2.726 \\
(1.299)\end{array}$ & $\begin{array}{c}1.731 \\
(0.843)\end{array}$ & 30 & 147 \\
\hline France & $\begin{array}{c}0.220 \\
(0.164)\end{array}$ & $\begin{array}{c}0.434 \\
(0.405)\end{array}$ & $\begin{array}{c}4.948 \\
(3.449)\end{array}$ & $\begin{array}{c}1.797 \\
(1.287)\end{array}$ & 131 & 600 \\
\hline Germany & $\begin{array}{c}0.186 \\
(0.126)\end{array}$ & $\begin{array}{c}0.332 \\
(0.354)\end{array}$ & $\begin{array}{c}4.239 \\
(2.833)\end{array}$ & $\begin{array}{c}2.353 \\
(1.735)\end{array}$ & 171 & 800 \\
\hline Italy & $\begin{array}{c}0.161 \\
(0.119)\end{array}$ & $\begin{array}{c}0.270 \\
(0.215)\end{array}$ & $\begin{array}{c}2.777 \\
(1.386)\end{array}$ & $\begin{array}{c}1.843 \\
(1.475)\end{array}$ & 53 & 229 \\
\hline Japan & $\begin{array}{c}0.127 \\
(0.083)\end{array}$ & $\begin{array}{c}0.153 \\
(0.136)\end{array}$ & $\begin{array}{c}2.766 \\
(1.563)\end{array}$ & $\begin{array}{c}1.789 \\
(1.394)\end{array}$ & 616 & 2298 \\
\hline Netherlands & $\begin{array}{c}0.190 \\
(0.095)\end{array}$ & $\begin{array}{c}0.327 \\
(0.178)\end{array}$ & $\begin{array}{c}3.948 \\
(2.383)\end{array}$ & $\begin{array}{c}2.905 \\
(2.343)\end{array}$ & 44 & 206 \\
\hline Spain & $\begin{array}{c}0.175 \\
(0.110)\end{array}$ & $\begin{array}{c}0.306 \\
(0.227)\end{array}$ & $\begin{array}{c}3.002 \\
(3.119)\end{array}$ & $\begin{array}{c}1.778 \\
(0.919)\end{array}$ & 30 & 129 \\
\hline UK & $\begin{array}{c}0.176 \\
(0.111)\end{array}$ & $\begin{array}{c}0.339 \\
(0.300)\end{array}$ & $\begin{array}{c}3.786 \\
(2.420)\end{array}$ & $\begin{array}{c}2.669 \\
(1.771)\end{array}$ & 233 & 1187 \\
\hline US & $\begin{array}{c}0.227 \\
(0.169)\end{array}$ & $\begin{array}{c}0.458 \\
(0.449)\end{array}$ & $\begin{array}{c}4.660 \\
(3.329)\end{array}$ & $\begin{array}{c}2.651 \\
(2.152)\end{array}$ & 1160 & 5670 \\
\hline $\begin{array}{l}\text { Whole } \\
\text { sample }\end{array}$ & $\begin{array}{c}0.197 \\
(0.149)\end{array}$ & $\begin{array}{c}0.365 \\
(0.385)\end{array}$ & $\begin{array}{c}4.097 \\
(2.980) \\
\end{array}$ & $\begin{array}{c}2.401 \\
(1.936)\end{array}$ & 2601 & 11979 \\
\hline
\end{tabular}


Table 2

Country variables

\begin{tabular}{lccc}
\hline & $\begin{array}{c}\text { Private credit by } \\
\text { deposit money banks } \\
\text { and other financial } \\
\text { institutions, } \\
\text { relative to GDP, } \\
\text { average 1992-1997 }\end{array}$ & $\begin{array}{c}\text { Stock market } \\
\text { capitalization, } \\
\text { relative to GDP, } \\
\text { average 1992-1997 }\end{array}$ & $\begin{array}{c}\text { Proportion of stock } \\
\text { market capitalization } \\
\text { held by banks }\end{array}$ \\
\hline Australia & 1 & 2 & 3 \\
Canada & 0.748 & 0.810 & 0.042 \\
Finland & 0.815 & 0.632 & 0.08 \\
France & 0.731 & 0.334 & 0.15 \\
Germany & 0.872 & 0.344 & 0.064 \\
Italy & 1.020 & 0.245 & 0.136 \\
Japan & 0.530 & 0.175 & 0.057 \\
Netherlands & 2.046 & 0.699 & 0.232 \\
Spain & 1.594 & 0.759 & 0.053 \\
United Kingdom & 0.744 & 0.321 & 0.095 \\
United States & 1.137 & 1.206 & 0.017 \\
\hline
\end{tabular}

Sources:

Columns 1-2: Calculated from data in the World Bank database 'Financial Structure and Economic Development', //www.worldbank.org

Column 3: Carlin and Mayer (2003). The values of this variable are for most countries the averages for 1980-1990. For three countries the averages are for a different period: Canada (1981-1990), Finland (1983-1990) and Italy (1985-1988). The data for the UK are for 1991. 
Table 3

Results of investment regressions for individual countries

\begin{tabular}{|c|c|c|c|c|}
\hline & $\begin{array}{c}\text { Market-to-book } \\
\text { ratio }\end{array}$ & Sales/capital & Cash flow/capital & Adjusted $R^{2}$ \\
\hline Australia & $\begin{array}{c}0.0333^{* * *} \\
(2.67)\end{array}$ & $\begin{array}{l}0.0181^{*} \\
(1.96)\end{array}$ & $\begin{array}{l}0.2050^{* * *} \\
(4.06)\end{array}$ & .28 \\
\hline Canada & $\begin{array}{l}0.0097 \\
(1.28)\end{array}$ & $\begin{array}{l}0.0271^{* * *} \\
(3.20)\end{array}$ & $\begin{array}{l}0.1504^{* * * *} \\
(3.95)\end{array}$ & .14 \\
\hline Finland & $\begin{array}{c}0.0381^{* *} \\
(1.99)\end{array}$ & $\begin{array}{l}0.1369^{* * * *} \\
(5.78)\end{array}$ & $\begin{array}{l}-0.0690 \\
(-1.37)\end{array}$ & .35 \\
\hline France & $\begin{array}{c}0.0127^{* *} \\
(2.36)\end{array}$ & $\begin{array}{c}0.0314^{* * * *} \\
(4.88)\end{array}$ & $\begin{array}{c}0.0656^{* *} \\
(2.07)\end{array}$ & .23 \\
\hline Germany & $\begin{array}{c}0.0083 \\
(0.17)\end{array}$ & $\begin{array}{l}0.0338^{* * *} \\
(5.40)\end{array}$ & $\begin{array}{l}0.0171 \\
(0.89)\end{array}$ & .19 \\
\hline Italy & $\begin{array}{c}0.0106^{* * *} \\
(1.90)\end{array}$ & $\begin{array}{l}0.0415^{* * *} \\
(3.35)\end{array}$ & $\begin{array}{l}0.1088^{* * * *} \\
(2.71)\end{array}$ & .20 \\
\hline Japan & $\begin{array}{l}0.0013 \\
(0.66)\end{array}$ & $\begin{array}{l}0.0416^{* * *} \\
(7.28)\end{array}$ & $\begin{array}{l}0.0251 \\
(1.18)\end{array}$ & .14 \\
\hline Netherlands & $\begin{array}{c}0.0043 \\
(1.15)\end{array}$ & $\begin{array}{c}0.0180^{* *} \\
(2.48)\end{array}$ & $\begin{array}{l}0.2209^{* * * *} \\
(4.97)\end{array}$ & .26 \\
\hline Spain & $\begin{array}{c}-0.0208^{*} \\
(-1.75)\end{array}$ & $\begin{array}{l}0.0173^{* * *} \\
(3.12)\end{array}$ & $\begin{array}{c}0.1216^{* *} \\
(2.32)\end{array}$ & .17 \\
\hline United Kingdom & $\begin{array}{c}0.0109^{* * *} \\
(2.94)\end{array}$ & $\begin{array}{l}0.0252^{* * *} \\
(6.26)\end{array}$ & $\begin{array}{l}0.1201^{* * * *} \\
(5.72)\end{array}$ & .24 \\
\hline United States & $\begin{array}{c}0.0095^{* * *} \\
(6.61)\end{array}$ & $\begin{array}{c}0.0320^{* * *} \\
(12.54)\end{array}$ & $\begin{array}{c}0.0842^{* * * *} \\
(10.45)\end{array}$ & .20 \\
\hline
\end{tabular}

Note: Dependent variable is capital expenditure divided by capital. Within estimations. Year dummies are included in all regressions. Newey-West heteroskedasticity consistent $t$-statistics are in parentheses

${ }^{*}$ Significant at 10 percent level.

** Significant at 5 percent level.

${ }^{* * *}$ Significant at 1 percent level. 
Table 4

Investment-cash flow intensities and characteristics of financial systems

\begin{tabular}{lcccc}
\hline & 1 & 2 & 3 & 4 \\
\hline $\begin{array}{l}\text { Dummy close bank- } \\
\text { firm relationships }\end{array}$ & $-0.1436^{* * *}$ & & & \\
Bank equityholdings & $(-3.91)$ & $-0.1814^{* *}$ & & \\
& & $(-2.33)$ & & \\
Credit/GDP & & -0.0032 & \\
& & $(-0.05)$ & 0.1113 \\
Stock market & & & $(1.41)$ \\
capitalization/GDP & & & 0.0988 & 0.0307 \\
Intercept & $0.1346^{* * *}$ & $0.1616^{* * *}$ & $(1.42)$ & $(0.59)$ \\
& $(7.03)$ & $(4.56)$ & -0.11 & .09 \\
\hline
\end{tabular}

Note: Dependent variable is cash flow coefficients from regressions of individual country samples, reported in Table 3. Number of observations is 11. OLS estimations. Newey-West heteroskedasticity consistent $t$-statistics are in parentheses

${ }^{* *}$ Significant at 5 percent level.

*** Significant at 1 percent level. 